\title{
ON THE EFFECTIVENESS OF USING QUANTITATIVE AVO ANALYSIS IN FLUID AND LITHOLOGY DISCRIMINATION IN AN OFFSHORE NIGER DELTA FIELD, NIGERIA
}

\author{
Adeoti, L.", Ikoro, C. O., Adesanya, O. Y., Ayuk, M. A., Oyeniran, T. A and Allo, O. J. \\ Department of Geosciences, University of Lagos, Akoka, Lagos, Nigeria. *Corresponding Author, Email: \\ lukuade@yahoo.com (Tel.: +2348034739175) \\ (Received: 24 $4^{\text {th }}$ July, 2018; Accepted: $1^{\text {st }}$ December, 2018)
}

\section{ABSTRACT}

\begin{abstract}
Quantitative Amplitude Variation with Offset (AVO) analysis of "Jay" Field, offshore Niger Delta, was carried out with a view to properly discriminating fluid and lithology using near, mid and far offset seismic and well data. Seismic and well data were interpreted and analyzed. Synthetic seismogram was generated using density $(\rho)$ and sonic logs. AVO modeling, seismic AVO attribute analysis and AVO inversion were carried out and the results from well log interpretation using 70-API gamma-ray cut-off, neutron-density over lay and resistivity logs revealed that the field consists of intercalation of sand and shale with typical deltaic depositional environment $\log$ signatures. Four identified sand reservoirs ( $a, b, c$ and d) with high resistivity values and negative separation in the neutron-density overlay suggested that the field was hydrocarbon bearing probably containing gas or condensate. Two sand reservoirs showed good rock physics results, 'Sand a' at 11,632 ft TVD with 18\% porosity $(\phi), 0.25$ water saturation $\left(\mathrm{S}_{\mathrm{w}}\right)$, decreasing ratio of compressional wave velocity to shear wave velocity $\left(\mathrm{V}_{\mathrm{p}} / \mathrm{V}_{\mathrm{s}}\right)$ and Poisson's ratio 0 relative to the background shale signified AVO response typical of a hydrocarbon bearing sand. 'Sand e' at 5,925 ft TVD, with 30\% $\phi$, Sw of 1, no change in $\mathrm{V}_{\mathrm{p}} / \mathrm{V}_{\mathrm{s}}$ and relative to the background shale implied that an AVO response was unlikely. Gradient analysis result for the synthetic seismic at the top and base of the two sands agreed with Rutherford's classification scheme for class IV AVO for 'Sand a' and no AVO response for 'Sand e'. AVO attribute analysis and impedance inversion of the seismic volumes confirmed AVO result for the two sands. The study established that AVO technique could be effectively used for fluid and lithology discrimination in the "Jay" Field, Niger Delta.
\end{abstract}

Keywords: Amplitude Variation with Offset (AVO), Seismic and Well data, Rock Physics, Reservoir Sands

\section{INTRODUCTION}

Several authors have shown that the Niger Delta Basin has spectacularly maintained a thick sedimentary apron and salient Petroleum geological features favorable for petroleum generation, expulsion and trapping from the Onshore through the Continental shelf and to the deep water terrains (Whiteman, 1982). From the very beginning of oil exploration in Nigeria in 1937, till early 1993, virtually all exploration and production activities were restricted to land and swamps. Where prospecting ventured offshore, it was in areas not greater than $200 \mathrm{~m}$ water depth. But then in 1993, the Federal Government opened a new frontier in oil and gas exploration, heralding the bright prospects of a promising future, by allocating some offshore blocks in water depths reaching $2500 \mathrm{~m}$. These deep water depths and greater depths than $2500 \mathrm{~m}$ will undoubtedly impact positively the country's production and reserve blueprint. Though these deep-water operations are technically challenging and massively capital intensive, experienced multinational companies have been awarded some deep offshore blocks and even ultra-deep concessions.

Seismic reflection method has been effective in such challenging areas in detecting structures capable of trapping hydrocarbon but among the various seismic technique for hydrocarbon detection and monitoring in the subsurface, the Amplitude Variation with Offset (AVO) analysis appears to be quite promising with pore fluid identification. Only AVO analysis, which requires special handling of the data, can distinguish lithology changes from fluid changes (Castagna, 1993; Chiburis et al., 1993; Adekanle and Enikanselu, 2013; Adeoti et al., 2017). Almost all major companies use AVO routinely as a tool to "de-risk" exploration targets and to better define the extent and the composition of existing hydrocarbon reservoirs (Omudu and Ebeniro, 2005; Castagna and Chopra, 2007; Adeoti et al., 2014; Schlumberger, 2014). 
The inability of the seismic data to properly discriminate the fluid and lithology types in "Jay" Field informed quantitative AVO analysis, fluid substitution modeling and rock physics analysis. These methods will integrate well and seismic data to provide detailed information even beyond the drilled region.

\section{GEOLOGY OF THE STUDY AREA}

The study area 'Jay' Field is located in the shallow offshore, South-Western Niger Delta, about 58 kilometers (31 Nautical miles) off the coast of Warri Delta state, Nigeria (Figure 1). The area covers about 29200 sq. feet (2.71 sq. kilometers). The study area lies within the shelf area of the Niger Delta. The Niger Delta is a prograding depositional complex within the Cenozoic Formation of Southern Nigeria. It covers an area of about 75,000 square kilometers. It extends from the Calabar Flank and the Abakaliki Trough in Eastern Nigeria to the Benin Flank in the west and it opens to the Atlantic Ocean in the southern territory. The delta protrudes into the Gulf of Guinea as an extension from the Benue Trough and Anambra Basin Provinces (Evamy et al., 1978). The Niger Delta Basin is situated in the Gulf of Guinea and extends throughout the Niger Delta oil and gas province. From the Eocene to the present (Fig. 2), the delta has prograded southwestward, resulting in depobelts that represent the most active portion of the delta at each developmental stage (Doust and Omatsola, 1990). There are three major lithostratigraphic units recognized in the Niger Delta: Akata, Agbada and Benin Formations (Short and Stauble, 1967) (Fig. 2). The Akata Formation is a shale unit recognised as the major source of oil and gas. The Agbada Formation consists of sands and shales units, while the Benin Formation is composed mainly of sands. These lithostratigraphic units form one of the largest regressive deltas in the world with an area of some $2500,000 \mathrm{~km}$ (Kulke, 1995), a sediment volume of 3 about 500,000 km and a sediment thickness of more than $10 \mathrm{~km}$ in the basin depocenter (Kaplan et al., 1994). The Niger Delta Province contains only one identified petroleum system. This system is referred to here as the Tertiary Niger Delta (Akata-Agbada) Petroleum System. The Tertiary Niger Delta is a sedimentary structure formed as a complex regressive off-lap sequence of clastic sediments ranging in thickness from 9,000 12,000 m (Etu-Efeotor, 1998). Starting from different depocentres, the Niger Delta Basin has coalesced to form a single united system since Miocene era. Due to the history or relative unbroken progradation throughout the Tertiary period, these three depositional lithofacies are readily identified despite local facies variations, as three regional and diachronons formations ranging from Eocene to Recent age (Short and Stauble, 1967).

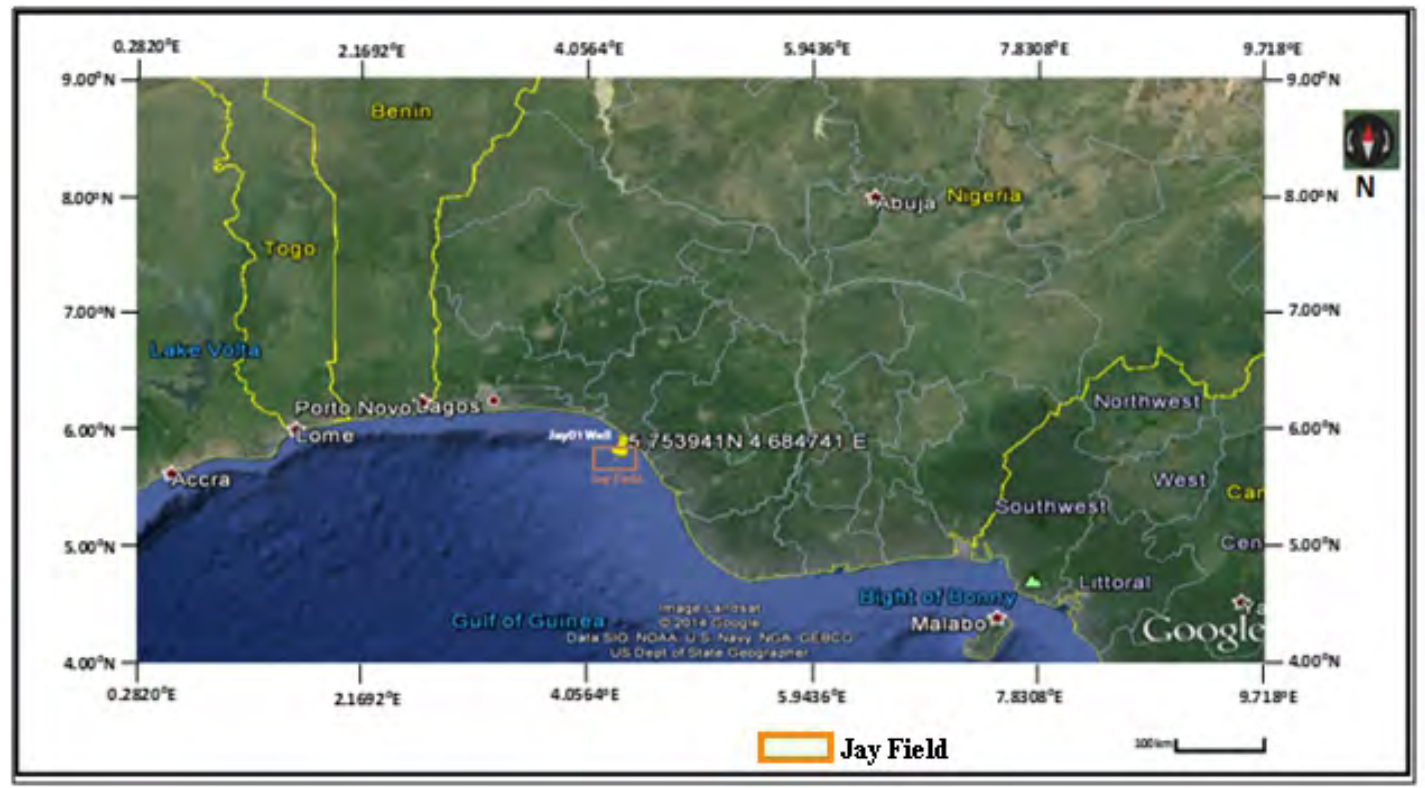

Figure 1: Location of 'Jay' Field, Offshore Niger Delta (Google Map) 


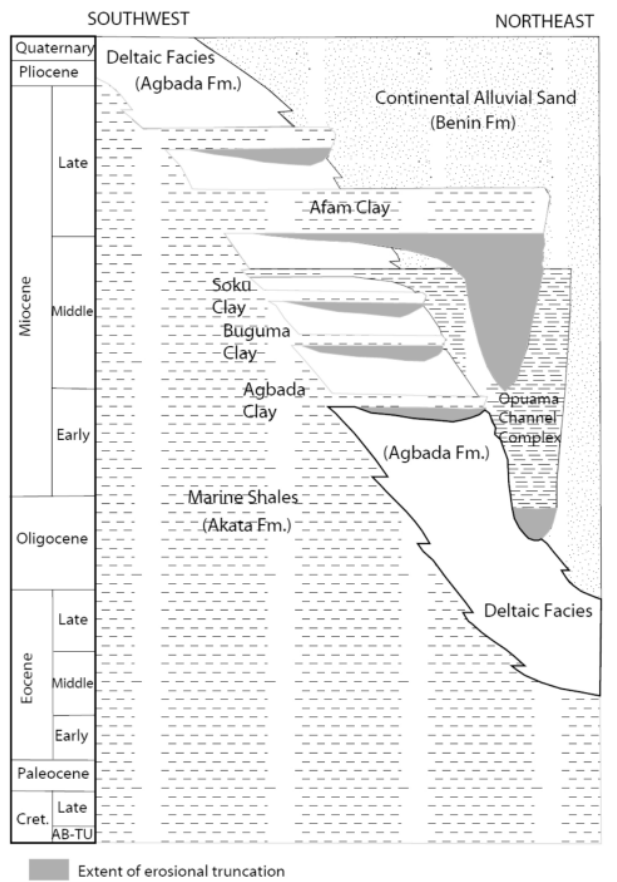

Figure 2: Stratigraphic Column Showing Formations of the Niger Delta (Modified from Doust and Omatsola, 1990).

\section{MATERIALS AND METHODS}

Seismic and well logs data used for this research were provided by Chevron Nigeria Limited through the Department of Petroleum Resources (DPR). The seismic data include: near, mid and far stacked volumes. The base map of the study area is presented in Figure 3. The well logs comprise gamma ray, resistivity, P-wave sonic $\left(\mathrm{V}_{\mathrm{p}}\right)$, density $(\rho)$, caliper, water saturation $\left(S_{w)}\right.$ and volume of shale $\left(\mathrm{V}_{\text {sh }}\right)$. However, only one well was made available and used for this study, Jay 01 well was drilled at Latitude $(5.753941 \mathrm{~N})$ and Longitude (4.684741E).

\section{Well Log Interpretation}

The well data were loaded and quality checked (QC) for any inconsistencies, editing and normalization. Well data consisting of gamma ray $\log$, resistivity $\log$, neutron $\log$, density $\log$ and sonic logs were employed for identifying anomalous zones, lithology discrimination, fluid content, porosity $(\phi), \mathrm{S}_{\mathrm{h}}$ and depositional environment in "Jay" Field. New logs were generated using empirical and theoretical transforms. Well logs were compared with seismic data and various cross plots of seismic attributes with log data were done. Two sand reservoirs: hydrocarbon bearing ('Sand a') and water bearing
('Sand e') were picked for the AVO analysis.

\section{Synthetic Seismogram}

The synthetic seismogram was generated by convolving the corrected sonic log and $\rho \log$ to get the impedance. The impedance was then used to generate a reflectivity stick which was then convolved with a wavelet to get the synthetics. A wavelet extracted from seismic was used to generate the synthetics for this study.

\section{Rock Physics Analysis}

The Rock Physics analysis was carried out using cross-plots. The acoustic impedance $\left(Z_{p}\right)$ versus Poisson ratio $(\sigma)$ was plotted and checked against four parameters water saturation $\left(\mathrm{S}_{\mathrm{w}}\right)$, resistivity, $\phi$, and volume of shale $\left(\mathrm{V}_{\mathrm{sh}}\right)$. The interpretation of the expected gas effect that plot outside the background trend was carried out according to Bacon et al. (2003).

\section{AVO Modeling and Seismic AVO Attributes}

The far, mid and near offset gathers were stacked to check for AVO effects. The AVO modelling was done through the creation of synthetic seismogram from logs after fluid substitution. Since post-stack seismic was used, attributes such 
as far-minus-near, (far-minus-near) multiplied by near and (far-minus-near) multiplied by far attributes were investigated; placed side by side for comparison for AVO effect. Cross-plot of near against far-near, an approximation of intercept versus gradient plot according to Castagna and Swan 1997 was carried out. The cross-plot interpretation was done using Castagna et al., 1998 AVO classification (Figures 4 and 5).

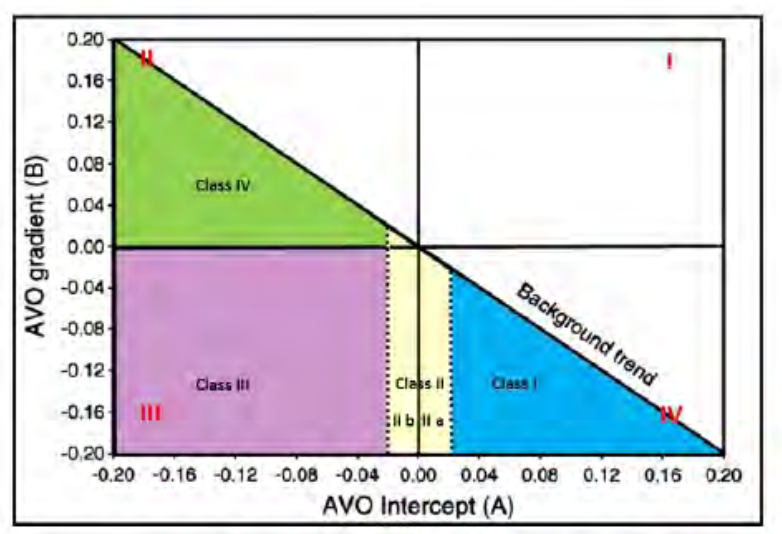

Figure 4: AVO Intercept (A) and Gradient (B) Crossplot (Castagna and Swan, 1997).

\section{RESULTS AND DISCUSSION}

\section{Well Log}

Figure 6 shows the well log interpretation with delineation of the sand and shale units. Four hydrocarbon bearing sands ( $a, b, c$ and $d$ ) were identified using a 70-API gamma ray cut-off in the second track, regions where the gamma ray reading falls below the cut-off point is classified as sand (displayed in yellow) while greater than 70API is classified as shale (displayed in ash color). In addition, gamma reading revealed blocky serrated signature. High resistivity response on the fifth track is associated with the four sand units while the neutron-density overlay shows a negative separation for the four sands suggesting

\section{AVO Inversion}

Model-based and Sparse-spike acoustic impedance (AI) inversion algorithms were applied to the integrated well and seismic data to identify impedance contrasts, possible fluid saturated zones and lateral extent of the reservoirs even beyond the drilled zones in "Jay" Field. The inversion was carried out using well $\operatorname{logs}(\rho$ and sonic), interpreted horizons, extracted wavelet and seismic volumes (near, mid and far). The QC of the inversion was done using the cross-plot of the well $\mathrm{Z}_{\mathrm{p}}$ against the inverted $\mathrm{Z}_{\mathrm{p}}$

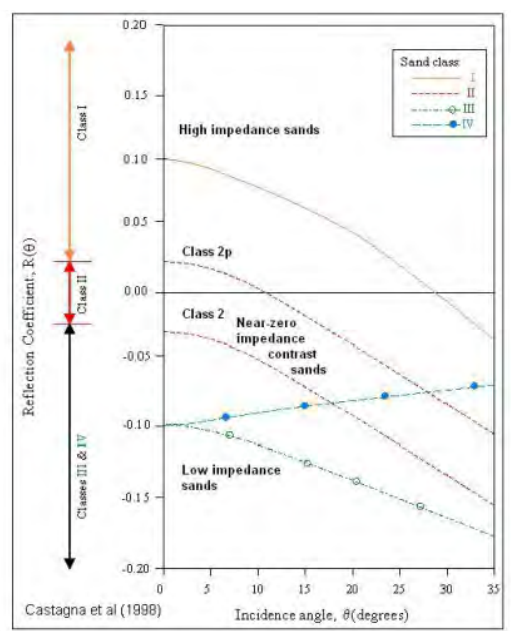

Figure 5: AVO Classification, Angle against Reflection Coefficient (Castagna et al., 1998)

presence of gas. A shallower 'Sand e' having low gamma ray and low resistivity response with the corresponding neutron-density log tracking on each other suggests water bearing sand reservoir. These are sands ( $a$ and e) selected for the AVO studies; 'Sand a' at 11,623 ft (3,536 m) TVD with $\phi$ $(18 \%)$ and $\mathrm{S}_{\mathrm{w}}(0.25)$ (sixth track), 'Sand e' at 5,925 ft $(1,806 \mathrm{~m})$ TVD with $\phi(30 \%)$ and $\mathrm{S}_{\mathrm{w}}(1)$.

\section{Synthetic Seismogram}

The wavelet generated from the well (elastic wave option) produces a synthetic seismogram with correlation coefficient of 0.5 (Figure 7). The synthetic seismogram was used for well-to-seismic tie for the study area. The wavelet shows amplitude with peak of about 1 . 


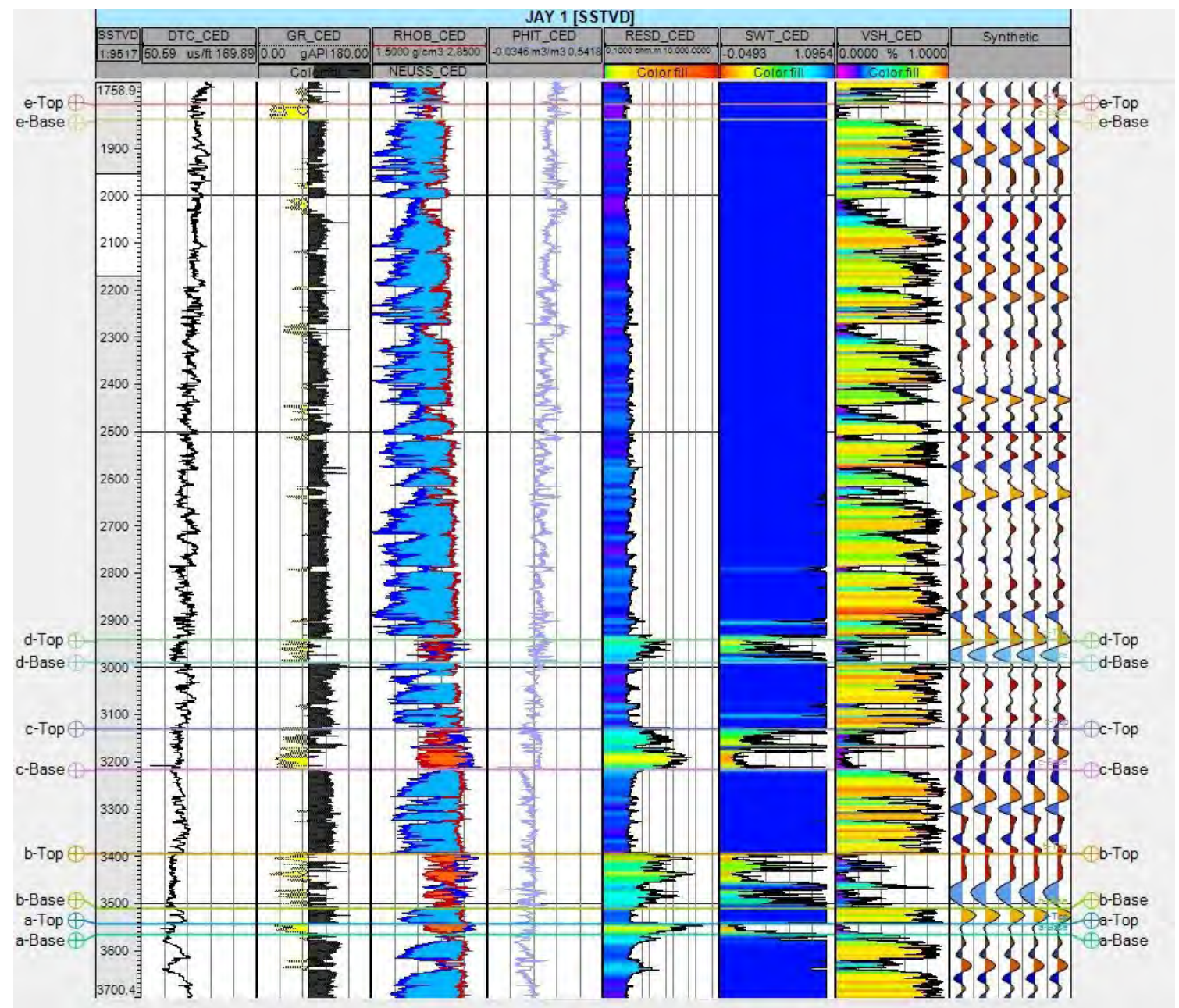

Figure 6: Identified hydrocarbon bearing Sands (a, b, c, d and e).

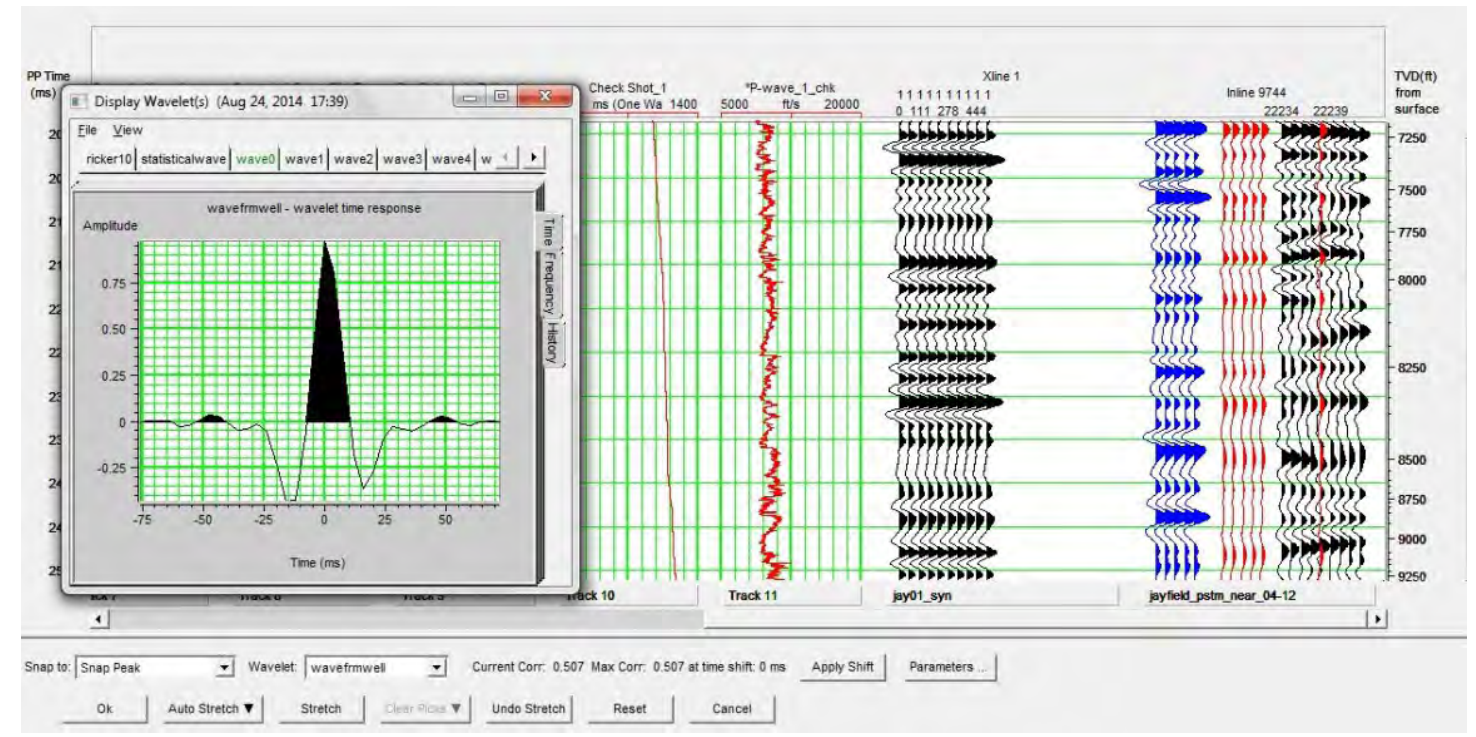

Figure 7: Synthetic Seismogram using Wavelet from "Jay 01". 


\section{Rock Physics Analysis}

Figure 8 shows the well correlation with the calculated rock physics parameters. The rock physics result for the hydrocarbon bearing sands show low $V_{p} / V_{s}$, low $\sigma$ and low $\mu-\lambda$; as against the background shale. Rock physics result for the water bearing sand show no change in the parameters suggesting that an AVO response is unlikely. Cross-plot analyses as shown in Figures 9 (a-d) revealed sands that are distinctively away from the background shale and are brine saturated lithology when colored by $\left(\mathrm{S}_{\mathrm{w}}, \phi, \mathrm{V}_{\mathrm{Sh}}\right.$ and resistivity) logs respectively.

Bacon et al. (2003) used as a model for the interpretation is inserted in Figure 9a. The analysis further revealed that these distinct plots coincide with the depth range of the hydrocarbon bearing sands picked from $\log$ with good $\phi(14 \%-28 \%)$, $\mathrm{S}_{\mathrm{w}}(<0.5), \mathrm{V}_{\mathrm{Sh}}(0.1-0.3)$ and resistivity of over 100 $\Omega \mathrm{m}$. The water bearing sand falls within the background trend. The result shows the AVO effect at the gas reservoirs.

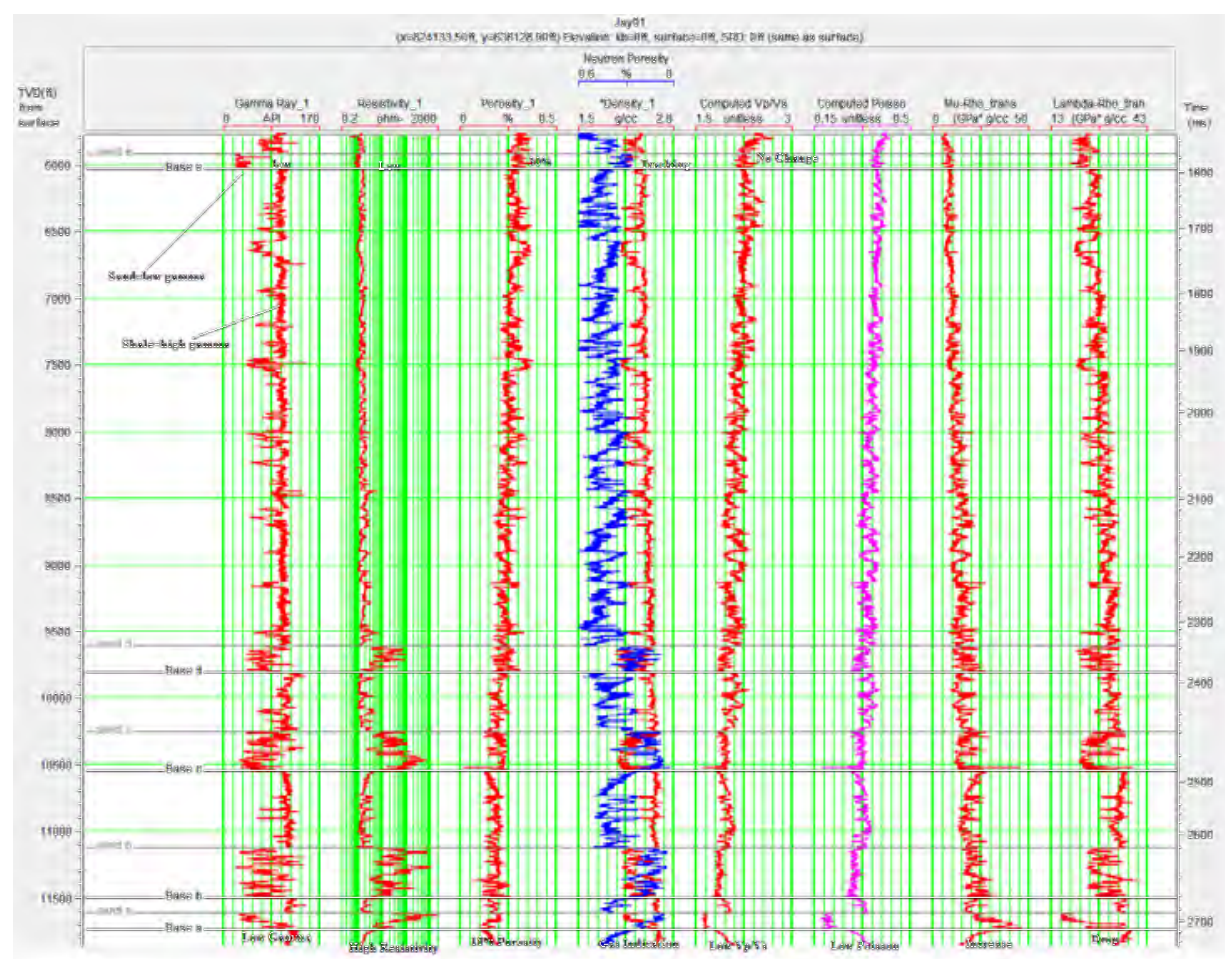

Figure 8: Rock Physics parameters for Sands ( $a, b, c, d$ and e).

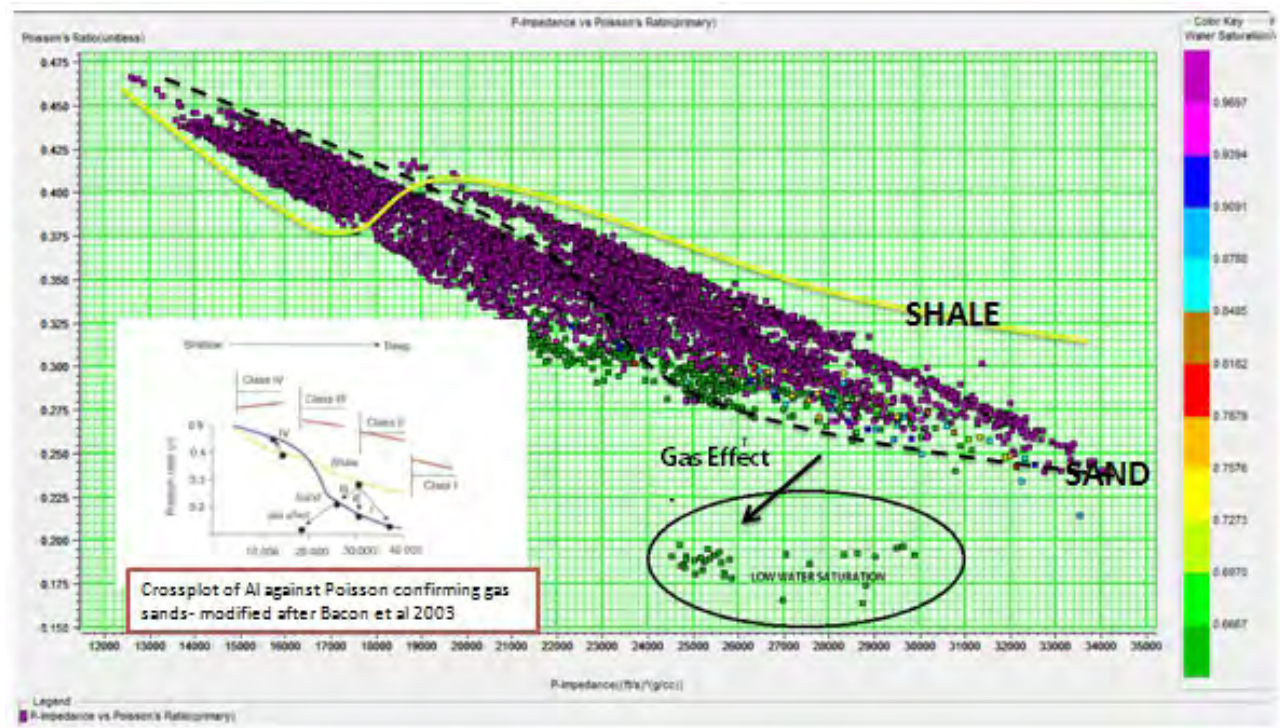

Figure 9a: Cross-plot of $\sigma$ against $Z_{p}$ color coded with $S_{w_{w}}$ 


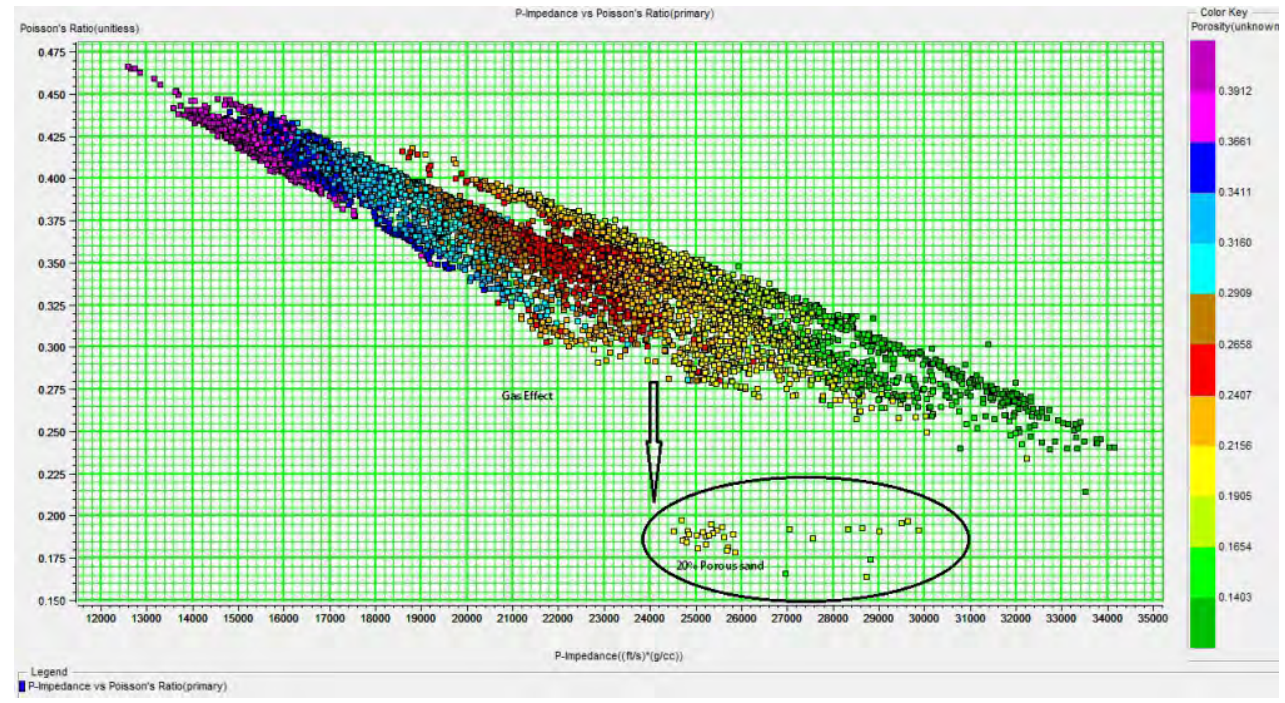

Figure 9b: Cross-plot of $\sigma$ against $Z_{\mathrm{p}}$ color coded with $\phi$.

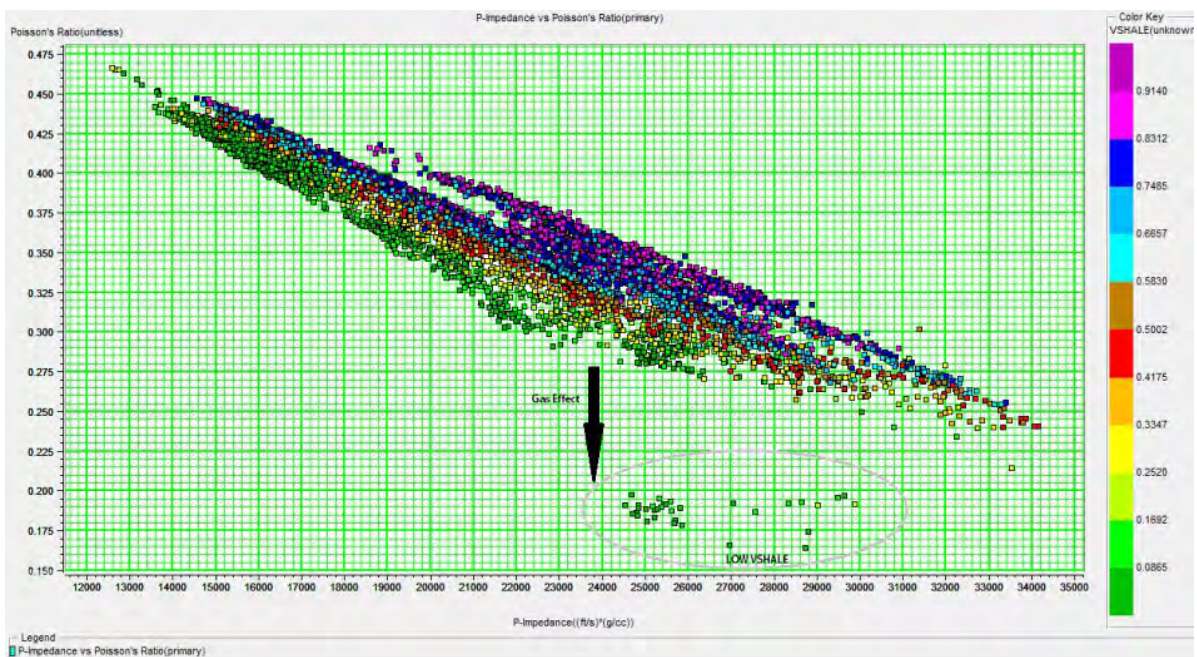

Figure 9c: Cross-plot of $\sigma$ against $Z_{p}$ color coded with $V_{\text {sh. }}$

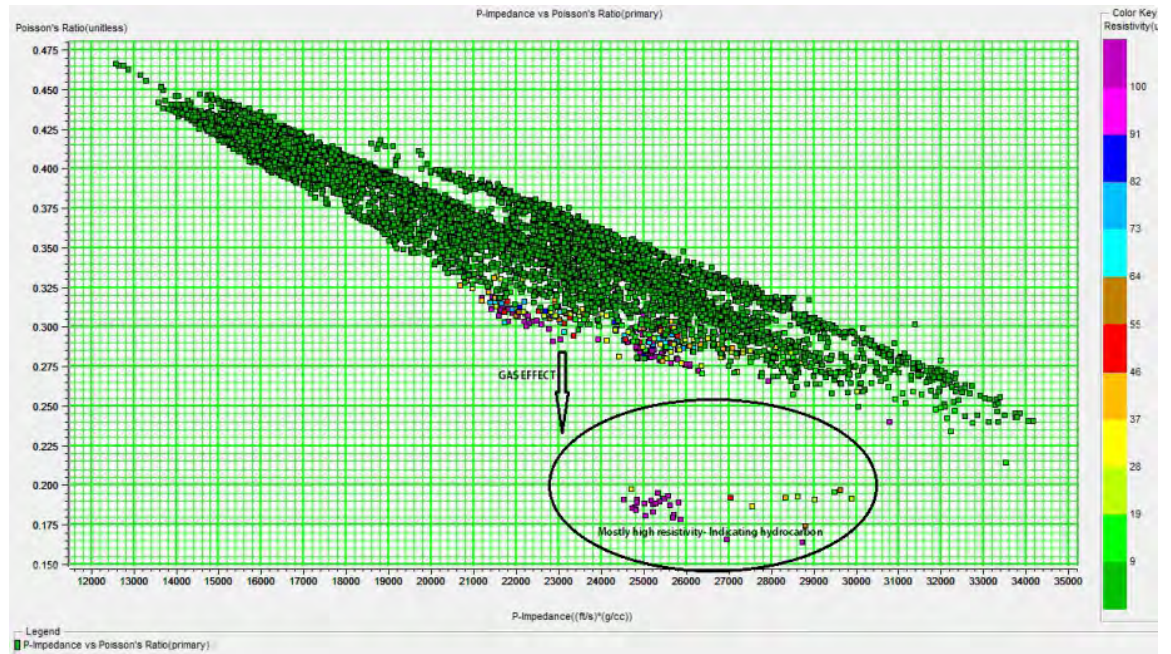

Figure 9d: Cross-plot of $\sigma$ against $Z_{p}$ color coded with Resistivity. 


\section{AVO Analysis}

Gradient analyses of the seismic wavelet derived synthetic for the top and base of 'Sand a' and 'Sand $\mathrm{e}^{\prime}$ (Figs. $10 \mathrm{a}$ and b) revealed AVO curve and intercept-gradient plot. A positive amplitude (Fig. 10a) that is neither rising nor falling is observed for top and base of 'Sand e', which is not a valid AVO response for hydrocarbon bearing reservoirs. For 'Sand a' (Fig. 10b), the base plots are along the background brine saturated trend while the top of the sand plots fall on the second quadrant which is distinct from the background trend and it is therefore qualified as a class IV AVO based on the Rutherford and Williams (1989) classification.
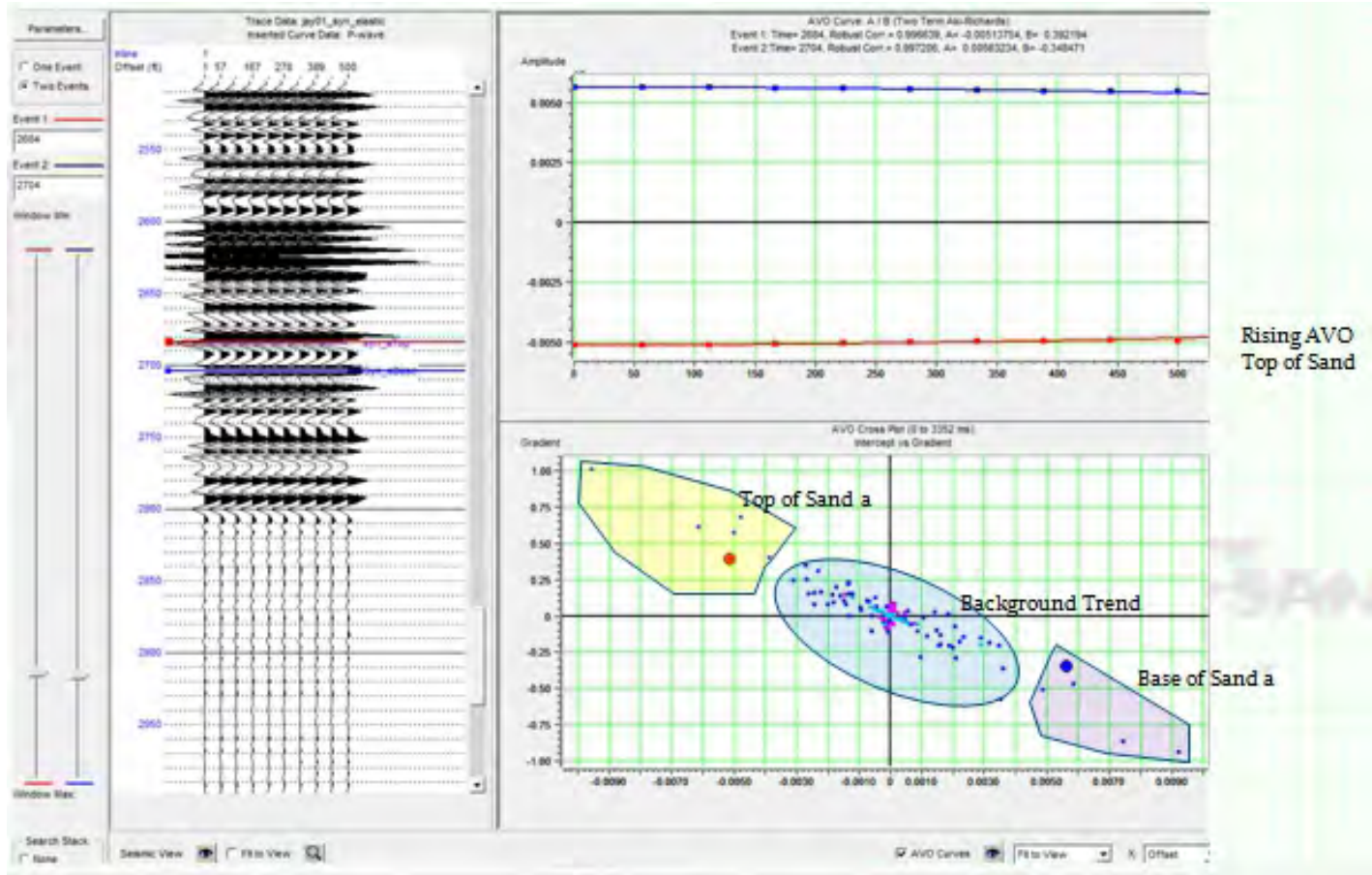

Figure 10a: Gradient Analysis for 'Sand a' according to Rutherford and Williams (1989).
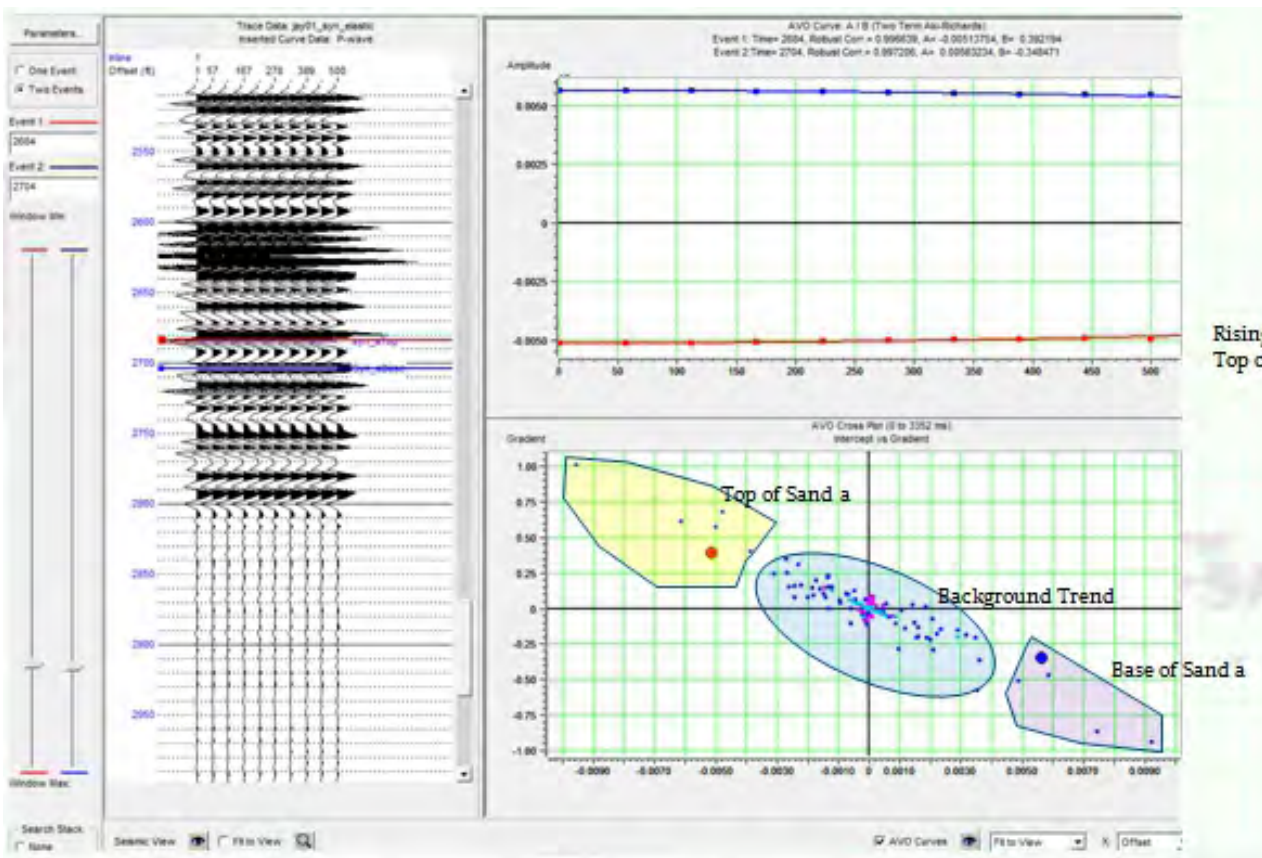

Figure 10b: Gradient Analysis for 'Sand e' according to Rutherford and Williams (1989). 


\section{Seismic Attributes Cross-plots}

Figures 11 ( $a$ and b) are the seismic attributes cross-plots which revealed that the 'Sand a' is class IV AVO). The top of sands on the seismic volume is the input for the cross-plot analysis. The plot towards the second quadrant as captured by the ash box (Fig. 11a) deviates from the background

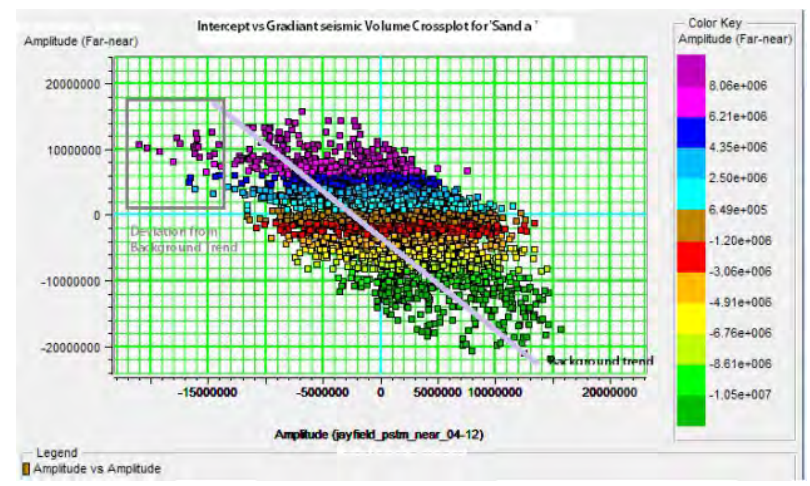

Figure 11a: Cross-plot of Gradient against Intercept for 'Sand a'.

\section{Comparison of Seismic Attributes}

Figure 12 shows the comparison between the original seismic (near, mid and far) and generated seismic attributes (far-minus-near and (far-minusnear) *far). The amplitude event decreases from the near offset to the mid offset and much more for the far offset as in captured white circles 'Sand a' region (Fig. 12). Seismic attributes (far-minus- trend and therefore is classified as class IV AVO response (after Castagna et al., 1998; Adeoti et al., 2017). Figure 11b, the cross-plot of Gradient against intercept for 'Sand e' does not show any significant deviation from background trend compared to Figure 11a.

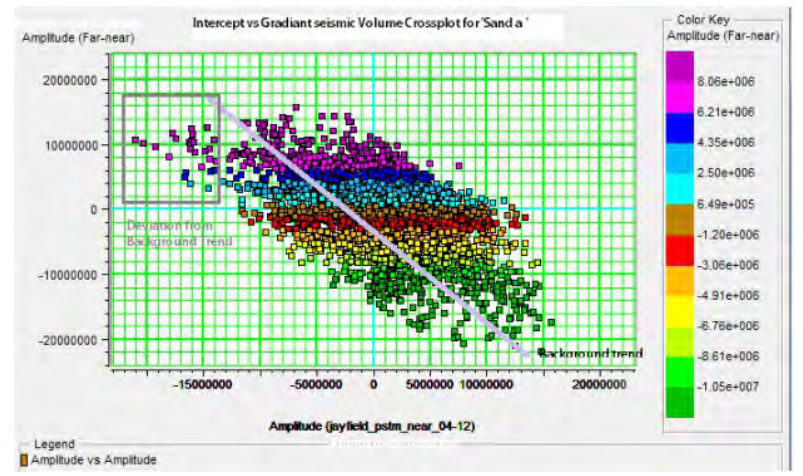

Figure 11b: Cross-plot of Gradient against Intercept for 'Sand e'.

near) and (far-minus-near) multiplied by far are good indicators of gas sands as revealed by their amplitude events. The seismic attributes also differentiated gas bearing reservoir sands (green with orange events on seismic) from shale-sand (sharp blue with often yellow in-between) interfaces with bright amplitude.

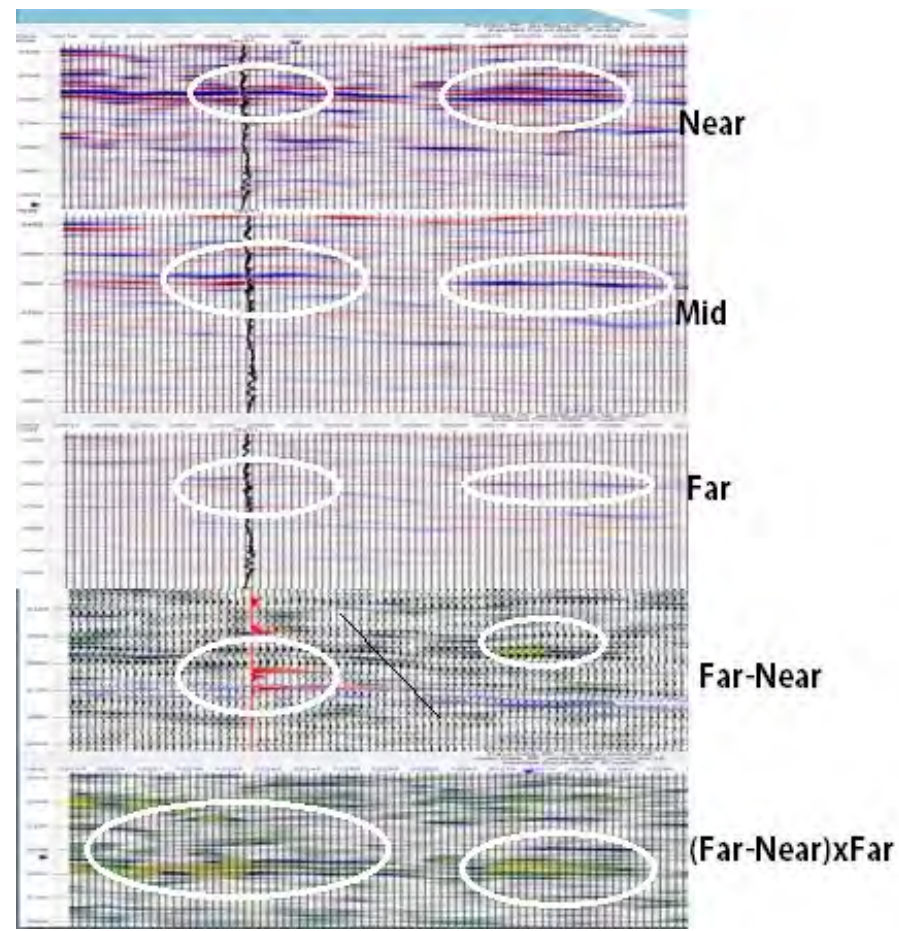

Figure 12: Comparison of the Seismic Attributes (far- near and (far- near*far) with Original Seismic (near, mid, far) Volumes. 


\section{AVO Inversion}

The model-based impedance inversion (Figure 13a) serves as the input for the other inversions. The model-based impedance inversion corresponds to the interpreted horizons used as input for the regions $Z_{p}$ contrast. Linear Sparse Spike impedance inversion is displayed in Figure $13 \mathrm{~b}$ which shows events of low impedance as seen from the drilled reservoir region and continuing beyond it, separated by faults. Impedance contrast showing in different color codes corresponds to different lithologies. The purple corresponds to shale while the blue with bright amplitude corresponds to fluid effect suggesting a hydrocarbon bearing sand. The insert of gamma and resistivity logs confirm the inversion result for lithology discrimination with a near perfect correlation. The correlation in Figures 13 (c and d) of the original information from the well $\log$ with the inverted data has error of 1196.61 for the $Z_{p}$; correlation of 0.97 for the synthetics and error of 0.23 , a good match between the horizons already picked from seismic and well log.

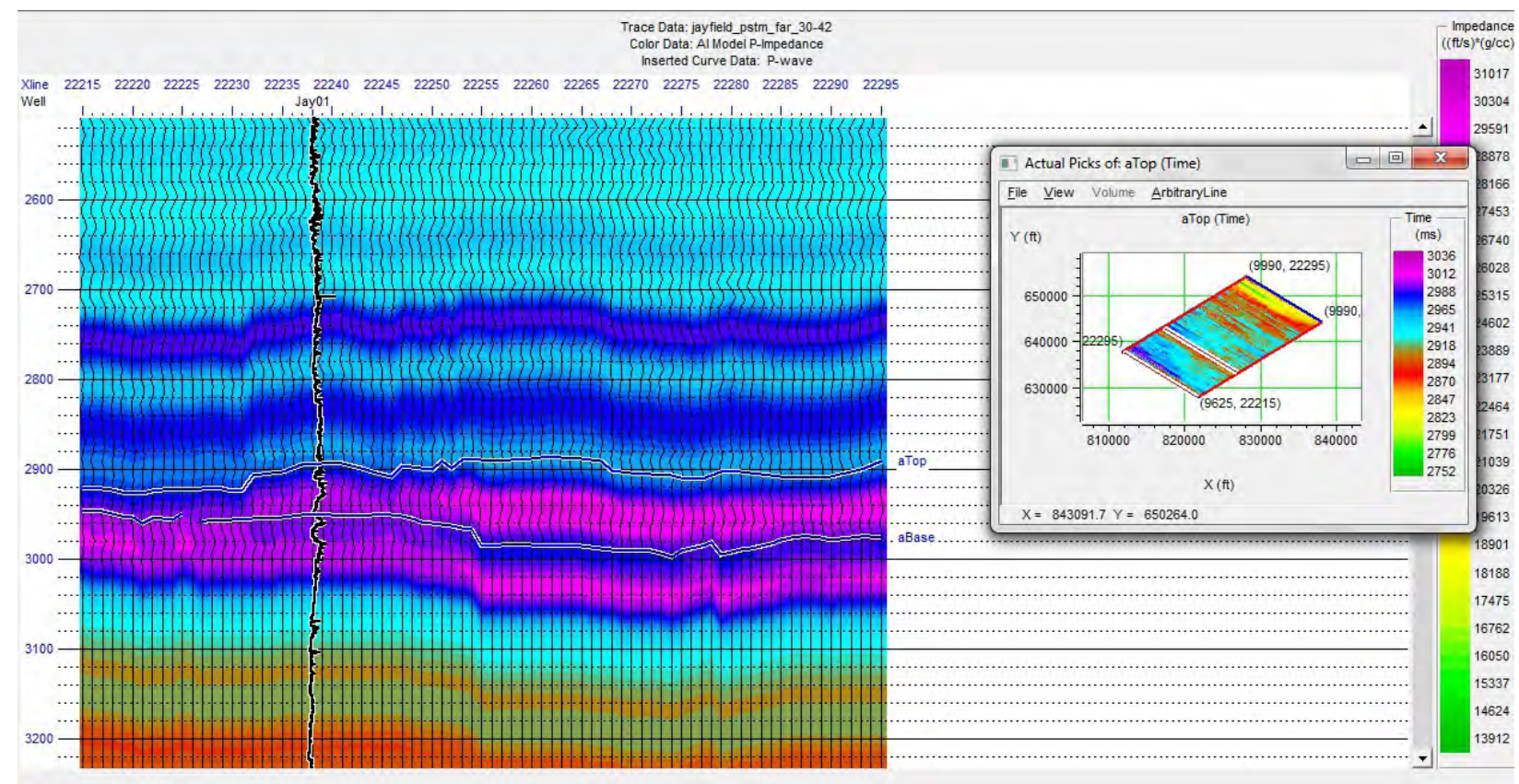

Time (ms)

Inline: 9744

Figure 13a: Model-base Inverted $\mathrm{Z}_{\mathrm{p}}$

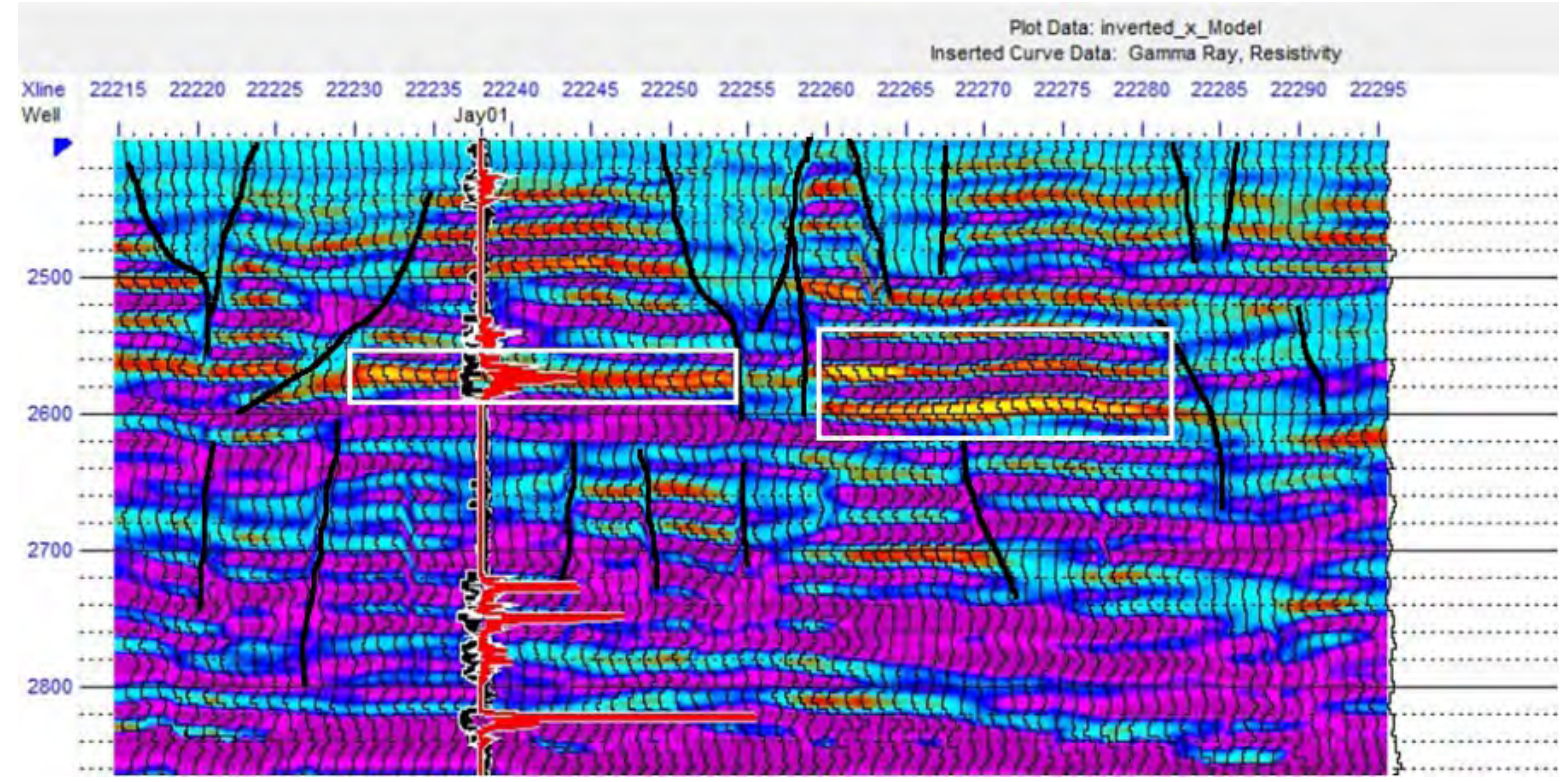

Figure 13b: Inverted Zwith inserted Gamma ray and resistivity logs. 


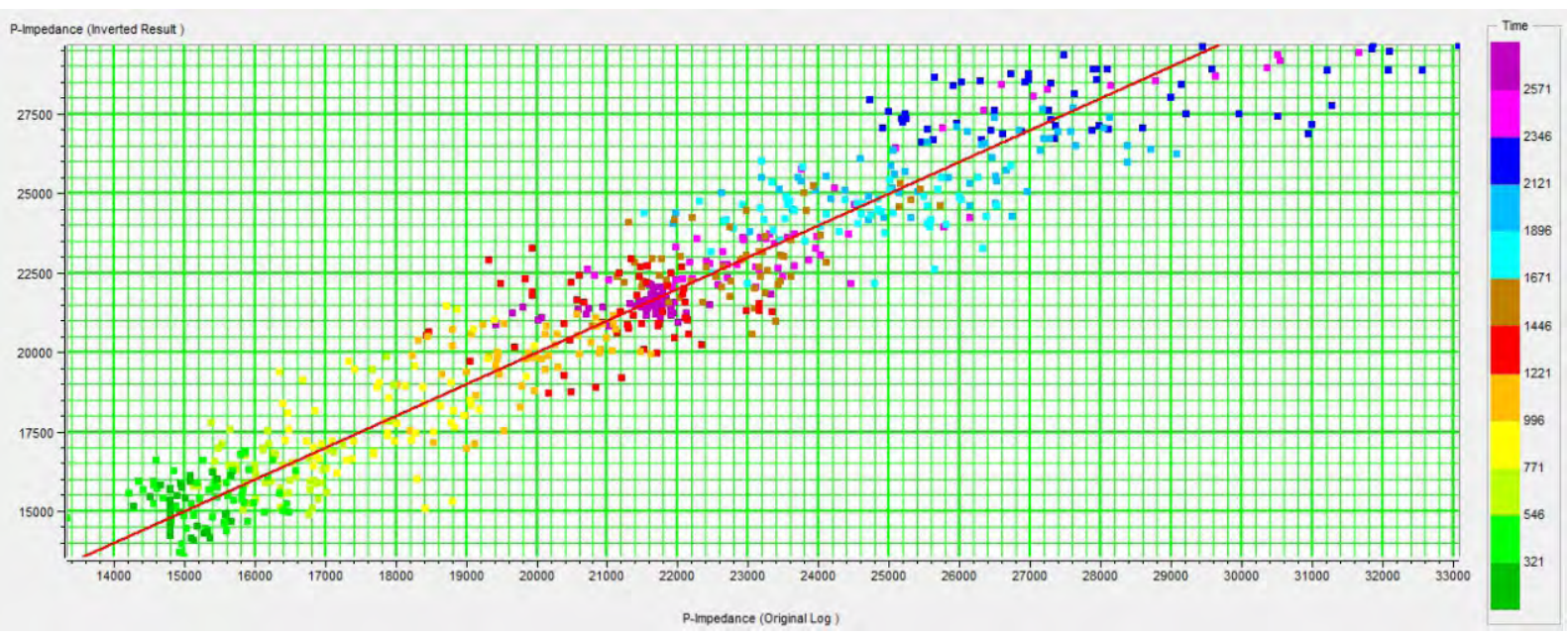

Figure 13c: Cross-plot of well Zpgainst Inverted $Z_{p}$

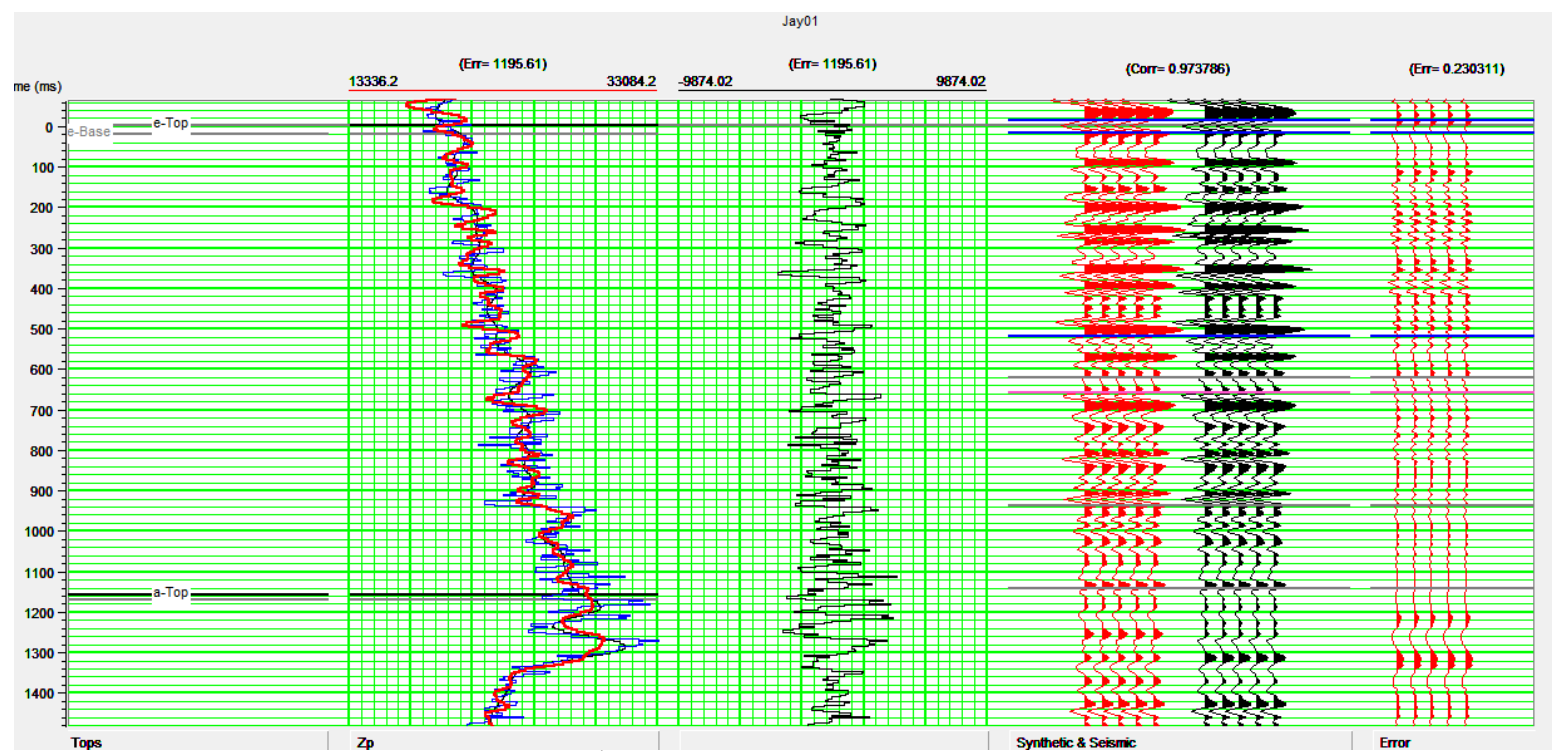

Figure 13d: Correlation of well $Z_{p}$ nd inverted $Z_{p}{ }_{p}^{\text {synteatc }}$

\section{CONCLUSIONS}

In this study, quantitative AVO analysis has been carried out on "Jay" Field data for lithology and fluid discrimination. Using gamma-ray cut-off of 70, four hydrocarbon sands (a, b, c and d) and water bearing 'Sand e' were identified. 'Sand a' at 11,623 ft depth and 'Sand e' at 5,925 ft depth were used for AVO analysis. The results from the Rock physics cross-plots show that gas sands explicitly plot away from the background shale and water saturated sands which indicates prospect in the study area.

Gradient analysis at the top and base of the two selected sands (a and e) agreed with the Rutherford and Williams (1989) classification scheme for class IV AVO for 'Sand a' but no AVO response for 'Sand e' which indicates that 'Sand a' is low impedance gas saturated Sands with negative reflection coefficient that decreases with offset while 'Sand $\mathrm{e}$ ' has positive reflection coefficient that neither increases or decreases with offset.

The seismic inversion results show 97\% correlation coefficient between the inverted $\mathrm{Z}_{\mathrm{p}}$ and well $Z_{p}$ which implies that seismic inversion is an effective tool in lithology and fluid prediction in "Jay" Field offshore, Niger Delta. The study has therefore shown that AVO could be a reliable tool for fluid and lithology discrimination in "Jay" Field. However, shear velocity information should be acquired to increase the accuracy of the procedure used in this study as against the empirically derived log used.

\section{ACKNOWLEDGEMENTS}

The authors wish to thank the Department of 
Petroleum Resources and Chevron Nigeria Limited for releasing the data for this study.

\section{REFERENCES}

Adekanle, A. and Enikanselu, P. A. 2013. Porosity Prediction from Seismic Inversion Properties over 'XLD' Field, Niger Delta, America Journal of Science and Industrial Research, 4(1), 31-35.

Adeoti, L., Adeleye, K.O., Itsemode, A. and Bello, M.A. 2014. Fluid prediction using AVO analysis and forward modelling of deep reservoirs in Faith Field, Niger Delta, Nigeria, Arabian Journal of Geosciences, 10:1-20.

Adeoti, L., Adesanya, O.Y, Oyedele, K. F, Afinotan, P., Adekanle, A. 2017. Lithology and fluid prediction from simultaneous seismic inversion over Sandfish field, Niger Delta, Nigeria, Geosciences Journal, 10:1-15.

Bacon, M., Simm, R. and Redshaw, T. 2003. 3-D Seismic Interpretation, Cambridge University Press, Ltd, UK. 212.

Castagna, J.P. 1993. Petrophysical Imaging using AVO, The Leading Edge, 12(3): 172-178, 342.

Castagna, J.P. and Chopra, S. 2007. Introduction to this special section - AVO, The Leading Edge, 26(12): 1506-1507.

Castagna, J.P. and Swan, H.W. 1997. Principles of AVO Cross-plotting, The Leading Edge, 116(4): 337-342.

Castagna, J.P., Swan, H.W., and Foster, D. J. 1998. Framework for AVO gradient and intercept interpretation: Geophysics, 63(3): 984-956.

Chiburis, E., Leaney, S., Skidmore, C., Franck, C. and McHugo, S. 1993. Hydrocarbon Detection with AVO, Oilfield Review. 5:1-3.
Doust, H. and Omatsola, E. 1990. Niger Delta. In: Divergent and Passive Margin Basin (Edwards P.A. and Santogrossi, P.A. eds.). Tulsa, USA, 45:239-248.

Etu-Efeotor, J.O. 1998. Stratigraphy, Sedimentology and Depositional Environment of Reservoir

Sands of the Ivo Field, Niger Delta, Global Journal of Pure and Applied Sciences, 4(3): 64-66.

Evamy, B.D., Haremboure, J., Kamerling, P., Knaap, W.A., Molloy, F.A. and Rowlands, P.H. 1978. Hydrocarbon Habitat of Tertiary Niger Delta, American Association of Petroleum Geologists Bulletin, 62: 277-298

Google Earth http:/ / earth.google.com

Kaplan, A., Lusser, C.V. and Norton, I.O. 1994. Tectonic Map of the World. Panel 10 Tulsa. American Association of Petroleum Geoscience Bulletin, 74:1-12

Kulke, H. 1995. Regional Petroleum Geology of the World. Part II: Africa, America, Australia and Antarctica: Berlin, Gebrüder Borntraeger, 143-172.

Omudu, L. M. and Ebeniro, J. O. 2005. Cross-plot of rock properties for fluid discrimination, using well data in offshore Niger Delta: Nigerian Journal of Physics, 17:16-20.

Rutherford, S.R. and Williams, R.H. 1989. Amplitude-versus-offset Variations in Gas Sands, Geophysics, 54: 680-688

Schlumberger Oilfield Glossary 2014. www.glossary.oilfield.slb.com

Short, K.C. and Stauble, A. 1967. Outline Geology of Niger Delta, American Association of Petroleum Geologists, 51: 761 - 776.

Whiteman, A. 1982. Nigeria: Its Petroleum Geology Resources and Potential, Grantman and Trontman, London. 1:394 